\title{
The ICCP-SS Technique for Retrofitting Reinforced Concrete Compressive Members subjected to Corrosion
}

DOI:

10.1016/j.conbuildmat.2018.01.096

\section{Document Version}

Accepted author manuscript

Link to publication record in Manchester Research Explorer

\section{Citation for published version (APA):}

Zhu, J., Su, M., Huang, J., Ueda, T., \& Xing, F. (2018). The ICCP-SS Technique for Retrofitting Reinforced Concrete Compressive Members subjected to Corrosion. Construction and Building Materials, 167, 669-679. https://doi.org/10.1016/j.conbuildmat.2018.01.096

\section{Published in:}

Construction and Building Materials

\section{Citing this paper}

Please note that where the full-text provided on Manchester Research Explorer is the Author Accepted Manuscript or Proof version this may differ from the final Published version. If citing, it is advised that you check and use the publisher's definitive version.

\section{General rights}

Copyright and moral rights for the publications made accessible in the Research Explorer are retained by the authors and/or other copyright owners and it is a condition of accessing publications that users recognise and abide by the legal requirements associated with these rights.

\section{Takedown policy}

If you believe that this document breaches copyright please refer to the University of Manchester's Takedown Procedures [http://man.ac.uk/04Y6Bo] or contact uml.scholarlycommunications@manchester.ac.uk providing relevant details, so we can investigate your claim.

\section{OPEN ACCESS}


Zhu, J.H., Su, M.N., Huang, J.Y., Ueda, T., Xing, F. (2018), "The ICCP-SS technique for retrofitting reinforced concrete compressive members subjected to corrosion", Construction and Building Materials, 167: 669-679.

\title{
The ICCP-SS Technique for Retrofitting Reinforced Concrete Compressive
}

\section{Members subjected to Corrosion}

\author{
Ji-hua ZHU1 ${ }^{1}$, Mei-ni SU²*, Jia-yi HUANG3, Tamon Ueda ${ }^{4}$, Feng XING ${ }^{5}$ \\ ${ }^{1}$ Associate Professor, Guangdong Province Key Laboratory of Durability for Marine Civil Engineering, \\ School of Civil Engineering, Shenzhen University, Shenzhen, Guangdong 518060, PR China. \\ ${ }^{2}$ Lecturer, School of mechanical, aerospace and civil engineering. University of Manchester, Manchester, \\ M1 7JR, UK (Corresponding author: meini.su@manchester.ac.uk) \\ ${ }^{3}$ M.Sc Candidate, Guangdong Province Key Laboratory of Durability for Marine Civil Engineering, \\ School of Civil Engineering, Shenzhen University, Shenzhen, Guangdong 518060, PR China. \\ ${ }^{4}$ Professor, Laboratory of Engineering for Maintenance System, Faculty of Engineering, Hokkaido Univ., \\ Sapporo 060-8628, Japan. \\ ${ }^{5}$ Professor, Guangdong Province Key Laboratory of Durability for Marine Civil Engineering, School of \\ Civil Engineering, Shenzhen University, Shenzhen, Guangdong 518060, PR China.
}

Abstract: Reinforced concrete (RC) stub columns are commonly featured in the construction industry, used in structures such as buildings and bridges. In coastal areas, bridge piers are subjected to serious corrosion damage, which may result in safety issues and huge economic losses. Currently, one of the most widely used retrofitting methods is the application of fiber reinforced polymer (FRP) sheets. This strengthening method can effectively improve the column capacities. However, as time goes by, the corrosion of re-bars will continue, leading to less force resistance. Impressed current cathodic protection (ICCP) is a well-known, efficient method to prevent further corrosion of the re-bars. Therefore, this study uses both ICCP and structural strengthening (SS) techniques to strengthen corroded RC columns. An experimental program consisting of 10 stub columns was carried out, including a 100-day accelerated corrosion process and 100-day ICCP protection and compression tests. Results show that the proposed ICCP-SS retrofitting method is not only effective in retarding the 
corrosion of steel but also capable of recovering the compression capacity of the corroded RC columns. In addition, comparisons between the test results and the predictions for RC column strengths by existing international design codes are made. The existing design methods were found to be conservative for the compression design of retrofitted columns.

Keywords: Cementitious material; carbon fiber mesh; corrosion; impressed current cathodic protection; reinforced concrete; structural strengthening; stub columns

\section{Introduction}

A variety of structures can be supported by reinforced concrete (RC) columns, including bridge decks and floor slabs. Columns may function as piers or piles, either above or below water level. While columns may vary in shape depending on their usage, circular-sectioned columns are typically used for ease of construction. Such columns may be subjected to corrosion issues due to a few reasons: some of the bridges are built by using sea-sand sea-water concrete; some are located in marine environments; some are exposed to winter deicing salts. Structural deterioration and a shortened lifespan of RC structures can be caused by the corrosion of embedded re-bars (Ahmad, 2003; McLeish, 1987; Lambert and MacDonald, 1998; Rodriguez et al., 1994).

Over the past 50 years, a number of technologies have been developed to tackle the corrosion of steel reinforcement in concrete. The most effective method of reducing or eliminating ongoing re-bar corrosion in RC structures is through cathodic protection 
(CP), especially in cases caused by chlorides (Revie and Uhlig, 2008; Bennett et al., 1993; Clemeña and Jackson, 2000). The selection of a suitable anode for the system is an important consideration in impressed current cathodic protection (ICCP) design, especially when it is to be used in reinforced concrete structures with their high resistivity (Lambert et al., 2015). Conductive carbon loaded paints, coated titanium expanded mesh or mesh ribbon in concrete overlays, and internal conductive ceramic Titania or coated titanium 'discrete' anodes are among some of the anodes currently used for $\mathrm{CP}$ systems. While some anodes are impractical due to their high cost, carbon fiber mesh is found to be a promising cathodic anode from a recent feasibility study (Zhu et al., 2014a; 2014b). However, it should be noted that the adoption of ICCP cannot recover the strength loss due to the existing corrosion of re-bars.

One of the most widely used techniques to improve the loading resistance of RC columns is to provide additional confinement to them. Rehabilitation of RC columns by external strengthening material has been extensively studied in the past few decades (Khalili and Fardis, 1982; Chai et al., 1991). One of the most popular strengthening materials is fiber reinforced polymer (FRP). A great number of studies on FRP strengthening have been carried out (Audenaert et al., 2005; Özcan et al., 2010; Juntanalikit et al., 2016; Eid and Paultre, 2017) because of its ease of formation, light weight, high strength, and relatively low cost. Previous researchers found that strengthened RC columns could have their loading capacities enhanced significantly. These beneficial effects are achieved because the confinement adds to the rigidity of the concrete column by preventing lateral expansion under axial load (Silva, 2011). 
There has been only limited research into the combination of these two remedial methods, which provide both strengthening and cathodic protection by using the electrically conductive properties and excellent durability of carbon fiber mesh (Lambert et al., 2015; Zhu et al., 2016a). Typical applications and most of the studies deal with either the ICCP system (Revie and Uhlig, 2008; Bennett et al., 1993; Clemeña and Jackson, 2000) or the strengthening of RC members (Khalili and Fardis, 1982; Chai et al., 1991; Audenaert et al., 2005; Özcan et al., 2010; Juntanalikit et al., 2016; Eid and Paultre, 2017). Little data (Lambert et al., 2015) exists for cases when ICCP is combined with the structural strengthening (SS) provided by anodes of carbon fiber mesh, while experimentation is required to study structural behavior and to optimize design procedures. The ICCP-SS dual-functional retrofitting technique for RC columns is a subject of ongoing research and development.

In the ICCP-SS system, both carbon fiber mesh and adhesive material have great impacts. Feasibility studies on both materials have been conducted by the authors (Zhu et al., 2016a, 2016b, 2017). In our previous studies, the behavior of carbon fiber mesh in the following three environments has been investigated: (1) the actual concentrations of the pore water components (Zhu et al., 2016a); (2) the chlorine evolution environment (Sun et al., 2016); and (3) the oxygen evolution environment (Zhu et al., 2016b). It was found that the degradation of carbon fiber mesh in the chlorine evolution environment is much more serious compared to the actual concentrations of the pore water components and the oxygen evolution environment. Furthermore, in order to simulate real cases, the performance of carbon fiber mesh in varying chloride 
concentrations has also been investigated (Zhu et al., 2017). The test results indicated that the degradation of carbon fiber was more significant in the lower chloride content solution with higher current density. In light of the test results and micro-structural mechanism analysis, promising conclusions on the residual strength and the service life of carbon fiber mesh after polarization were drawn (Audenaert et al., 2005; Özcan et al., 2010; Juntanalikit et al., 2016; Eid and Paultre, 2017). The service life of carbon fiber mesh can be more than 40 years even in serious polarization condition. As for the adhesive material used for bonding carbon fiber mesh, literature can be found on both organic and inorganic material. In the study on the ICCP-SS technique conducted by (Revie and Uhlig, 2008), epoxy resin was initially employed as the adhesive material; later, in order to improve the bonding behavior, a combination of geopolymer and epoxy was proposed and used in the experimental program (Nguyen et al., 2016). Meanwhile, in recent years, some investigations have been focused on a cement-based composite system (Basalo et al., 2012; Ombres, 2014; Ombres and Verre, 2015). Cementitious material provides excellent resistance to fire and high temperature, as well as good mechanical performance. Zhu et al. (2017) also presented the ingredients of a cementitious material, which were found to have great average bonding strength and a favorable failure mode in single shear tests.

This study proposes a dual-functional retrofitting technique for RC columns subjected to corrosion, which is termed as impressed current cathodic protection structural strengthening (ICCP-SS). Both the anodic material and the strengthening material in the ICCP-SS system are carbon fiber mesh. A novel modified cement-based 
inorganic cementitious material is adopted as the adhesive material. In this paper, an experimental program of circular RC columns is studied in order to examine the effectiveness of the ICCP-SS technique on RC columns. The columns were constructed with typical internal steel reinforcement in order to simulate the practice of retrofitting in-situ damaged columns. In addition, the beneficial effects of the ICCP-SS technique are shown by comparison with reference columns, i.e., columns without any repairing treatment. Finally, different design codes for confined concrete columns are used to predict the design capacities of the experimental specimens.

\section{Experimental program}

An experimental program that included the testing of 10 reinforced concrete stub columns was carried out in the structural laboratory of Shenzhen University. A certain amount of $\mathrm{NaCl}$ was contained in the concrete mix to introduce accelerated corrosion on the test specimens. The main target of the experimental program was to establish a database compiled from the experimental results.

\subsection{Test specimens}

The 10 test specimens can be divided into five groups: (1) one specimen did not contain any $\mathrm{NaCl}$ (i.e., a reference specimen); (2) two specimens contained $\mathrm{NaCl}$ but were not subjected to any repair technique (i.e., reference specimens); (3) three specimens contained $\mathrm{NaCl}$ and were repaired by the ICCP technique; (4) one specimen contained $\mathrm{NaCl}$ and was repaired by the SS technique; (5) three specimens contained $\mathrm{NaCl}$ and 
were repaired by the ICCP-SS technique. The weight of $\mathrm{NaCl}$ in the concrete mix was $3 \%$ of the cement mass. After the curing period, the specimens were exposed to accelerated corrosion, followed by the ICCP. The labeling system of the specimens is given in Table 1.

The experiment studies how effective ICCP-SS retrofitting systems are when applied to columns with an insufficient ratio of transverse reinforcement, such as might occur in corrosion-affected structures or older structures. The diameter of the columns is $200 \mathrm{~mm}$, and the overall height is $750 \mathrm{~mm}$. The nominal diameter of the longitudinal re-bars is $10 \mathrm{~mm}$, while the nominal diameter of stirrup is $6 \mathrm{~mm}$. The low amount of stirrup (i.e., a reinforcement ratio of $1.5 \%$ ) was representative of outdated building applications that typically would need retrofitting. Note that the lower limit of the reinforcement ratio specified in the code (China Academy of Building Research, 2015) is $0.55 \%$. The details of internal reinforcement and dimensions of column specimens are shown in Fig. 1.

\subsection{Material properties}

The average 28-day compression strength from concrete cubic tests was found to be $53 \mathrm{MPa}(\mathrm{C} 40)$. The concrete mixture proportion is presented in Table 2 . Two sizes of rebars -6 and $10 \mathrm{~mm}$ were used in the specimens. The material properties of carbon fiber mesh (see Fig. 2) were obtained through tensile tests according to the ASTM D4018 Standards (ASTM, 2017). The inorganic cementitious adhesive material was mixed according to the ingredients in Table 3 , and the material properties were also obtained 
via coupon tests. A typical stress-strain curve of the carbon-fabric reinforced cementitious matrix (C-FRCM) composite comprising one layer of carbon fiber mesh and cementitious material obtained from the tensile coupon tests is shown in Fig. 3. The thickness of the C-FRCM coupon is $28 \mathrm{~mm}$. The average material properties of concrete cube, re-bars, carbon fiber mesh and cementitious material are presented in Table 4. Three tests have been conducted to obtain each material property, and the coefficient of variation for each material property is less than 0.100 .

\subsection{Accelerated corrosion procedure}

An accelerated technique was used to induce damage due to corrosion in the test specimens within a reasonable period. $\mathrm{NaCl}$ was added so that approximately $3 \%$ chloride by weight of cement was placed in the concrete mix to simulate the sea-sand sea-water concrete. This amount of chloride was sufficient to cause the depassivation of the reinforcement and initiate corrosion (Zhu et al., 2017). No $\mathrm{NaCl}$ was added to the concrete mix for the control specimen (specimen CO). Afterwards, the specimens were placed in an open-air space for 28 days of curing. All the specimens underwent two wet-dry cycles per week, with each cycle consisting of two-and-a-half wetting days and one drying day. The accelerated corrosion process lasted for 100 days. The electrically accelerated corrosion technique is not used herein to avoid the influence of the internal electric field.

\subsection{ICCP}


Three steps were used to attach the carbon fiber mesh. Firstly, a $3 \mathrm{~mm}$ thick layer of cementitious material was pasted on the concrete surface; secondly, one layer of the carbon fiber mesh was tightly placed on the top of the cementitious material, and lightly pressed to improve the wettability; finally, a top $3 \mathrm{~mm}$ thick cementitious material layer was applied to cover the carbon fiber mesh and slightly pressed to remove the bubbles. Afterwards, the specimens were kept at room temperature and normal humidity conditions for 45 days before the application of ICCP.

After the accelerated corrosion procedure, one layer of the carbon fiber mesh was bonded to the surface of columns, except for the three reference specimens $(\mathrm{CO}, \mathrm{CO}-$ $\mathrm{C}$, and $\mathrm{CO}-\mathrm{C}-\mathrm{R})$. The columns were wrapped using transverse lap joints measuring approximately $150 \mathrm{~mm}$ (Ombres, 2014). The ICCP was applied to the corroded reinforced concrete beams by connecting the reinforcing steel to the negative terminal and the carbon fiber mesh anode to the positive terminal of a multi-channel DC power supply. The ICCP systems were operated in a laboratory environment for 100 days (Fig. 4). The applied currents were either $26 \mathrm{~mA} / \mathrm{m}^{2}$ (small current density) or $80 \mathrm{~mA} / \mathrm{m}^{2}$ (large current density) of steel area. For the specimens designed to be repaired by ICCP only, the carbon fiber mesh was torn off after the ICCP treatment.

During the corrosion process, the corrosion activity within each test specimen was monitored using internal probes and external instrumentation. Each column was equipped with a reference calomel electrode placed vertically on the upper surface during the steel cage assembly before the concrete was added. The measurement was 
conducted according to the ASTM C876-91 Standard guide (ASTM, 2009). The current was monitored, while the open circuit potential values for the embedded steel were recorded every three days.

\subsection{Stub column tests}

The test setup is shown in Fig. 5. Compressed between fixed ends, the columns were restrained against rotation, twisting, and warping. The ends of all columns were reinforced with iron rings to prevent premature failure beyond the test region. A servocontrolled hydraulic testing machine was used to apply the compression load. A constant rate of $0.4 \mathrm{~mm} / \mathrm{min}$ displacement control was used during testing, while the load was recorded by using a calibrated load cell placed between the jack and the reaction frame. The vertical deformation of the specimens was measured by three 25 mm range LVDTs (linear variable differential transducers), located between the upper and lower end plates. Another two LVDTs were used to measure the lateral displacements. The precision of the LVDT is $0.2 \mathrm{~mm}$. Strain gauges attached at $250-\mathrm{mm}$ intervals in the lateral direction were used to measure the lateral concrete/carbon fiber mesh strains. The applied load and readings from the strain gauges and LVDTs were recorded at 1 -second intervals by a data-logger during the tests.

\section{Results}

\subsection{Results of ICCP}

During the 100-day operation of the ICCP, the open circuit potential values of the re- 
bars of all the specimens were recorded during the wet cycles and plotted in Fig. 6. In accordance with the recommendations of Concrete Society Technical Report number 73 (the Concrete Society, 2001), if the open circuit potential value is greater than -126 $\mathrm{mV}$, it demonstrates that the embedded steel has only $10 \%$ chance of being corroded; if the open circuit potential value is less than $-275 \mathrm{mV}$, it demonstrates that the embedded steel has $90 \%$ chance of being corroded; if the open circuit potential value is between these two values, it means the status of the re-bars is uncertain. From Fig. 6, it can be seen that the open circuit potential values of the re-bars in the reference beam without $\mathrm{NaCl}$ (specimen $\mathrm{CO}$ ) is above the $-126 \mathrm{mV}$ level during the whole monitoring period. The specimens with $\mathrm{NaCl}$ were generally below the level of $-275 \mathrm{mV}$. When the ICCP starts to operate, the potential increases and gets closer to the margin of -126 $\mathrm{mV}$ as time goes by. For the specimens that contained $\mathrm{NaCl}$ but hadn't been protected by ICCP, the potential keeps decreasing and being well below the $-275 \mathrm{mV}$ level. Please note that no corrosion products or cracks were observed during the 100-day ICCP treatment. After the compression tests, the re-bars were taken to observe the corrosion level. According to the inspection, the noticeable corrosion of re-bars was not observed from those columns which have been protected by ICCP, while more pronounced corrosion of re-bars was observed from those columns without ICCP treatment. The mass loss of the re-bars will be measured in the future work.

\subsection{Results of compression tests}

The applied loads and the readings of the strain gauges and LVDTs were recorded. The load-deformation curves are plotted in Fig. 7, while results from the test are summarized 
in Table 5.

For the reference column (CO), the load capacity is $1545 \mathrm{kN}$, while for corroded specimens without any treatment (CO-C and CO-C-R), the load capacities are $1286 \mathrm{kN}$ and $1331 \mathrm{kN}($ average load $=1309 \mathrm{kN})$, respectively, which are $16.8 \%$ and $13 \%$ lower than that of the reference beam, respectively. The reason for the lesser load capacities might be related to the reduction of the cross-sectional area of the longitudinal re-bars. The corresponding ultimate deformation (i.e., the deformation corresponding to the ultimate capacity) of the reference column is $1.1 \mathrm{~mm}$, which is less than all other columns.

The ultimate strength of the column strengthened with carbon fiber mesh without ICCP (CO-C-F1) is $1687 \mathrm{kN}$, which is $28.9 \%$ higher than the average ultimate strength of un-strengthened columns (CO-C and CO-C-R). This shows that carbon fiber mesh can effectively improve the compression capacity of corroded columns. Moreover, column CO-C-F1 showed more ductile behavior (larger deformation) than the corroded columns.

Three corroded columns were protected by only ICCP after accelerated corrosion. Two values of current densities used in ICCP were chosen, i.e., a small current density of $20 \mathrm{~mA} / \mathrm{m}^{2}$ (CO-C-IS and CO-C-IS-R) and a large current density of $80 \mathrm{~mA} / \mathrm{m}^{2}$ (COC-IL). The compression strengths of these columns were found to be $1605 \mathrm{kN}, 1520$ $\mathrm{kN}$, and $1597 \mathrm{kN}$ for CO-C-IS, CO-C-IS-R, and CO-C-IL, respectively, which are $16.1 \%$ - 22.6\% higher than the unstrengthened columns (CO-C and CO-C-R). This demonstrates that ICCP can effectively impede the further corrosion of re-bars. It 
should also be noted that the capacities of the two columns protected by ICCP treatment (1605 kN and $1597 \mathrm{kN})$ are even higher than the reference column $\mathrm{CO}(1545 \mathrm{kN})$. This might be explained by the discreteness of the concrete material.

A total of three corroded columns retrofitted by the ICCP-SS method (CO-C-F1IS, CO-C-F1-IL, and CO-C-F1-IL-R) were tested. The compressive strengths of these columns were found to be $1801 \mathrm{kN}, 1969 \mathrm{kN}$, and $1664 \mathrm{kN}$, which have $37.6 \%, 50.4 \%$, and $27.1 \%$ increases, respectively, compared to the unstrengthened columns. In comparison with the columns repaired by only SS, it is found that the ICCP-SS technique showed a slight advantage (with up to a $16.7 \%$ increase in compression capacity). The reason for this is because the ICCP-SS technique impedes further corrosion of re-bars once the ICCP method is adopted, and also recovers the strength loss of the corroded specimens; while for the specimens repaired by the SS technique, corrosion of re-bars continues. However, it should be also noted that the duration of the accelerated corrosion and cathodic protection is relatively short compared to the application in practical cases, which would range from 50-70 years. The effectiveness of the ICCP-SS technique should be investigated for a longer duration.

\subsection{Failure modes}

Sudden failure in the unconfined columns was due to concrete crushing between the upper part and the mid-span of the columns (see Fig. 8(a)). Apart from the columns strengthened by FRP with epoxy resins, the failure of the columns confined with carbon fiber mesh and cementitious material occurred in a more gradual manner. A main 
vertical crack in the cementitious material propagated slowly at the top of the column surface, and the confined column failed when the crack became wider and the carbon fiber mesh ruptured in the hoop direction. (see Fig. 8(b)). Upon occurrence of major cracks in the cementitious material, the stiffness of the confining jackets changed and became nonlinear even before the peak loads of the columns were reached (see Fig. 3). At failure, both transversal and longitudinal cracks were observed. The hoop strain and lateral displacement became greater when cracks occurred. Two typical series of loadstrain and load-displacement curves for unconfined and confined columns are shown in Fig. 9. The loading behaviors of other columns are similar to these two typical specimens.

\section{Result comparisons and discussion}

\subsection{Discussion on loading capacities}

As summarized in Table 5, the corroded columns not subjected to any repair methods (CO-C and CO-C-R) have the lowest compression capacities. It can be seen that the accelerated corrosion process is effective, and the corrosion of re-bars has caused the deterioration of the RC columns. For all repaired columns, an increase in the loadcarrying capacity was observed compared to the unrepaired corroded ones. However, the effects of different current densities are not distinct in the experimental findings in this study, which is mainly attributed to the relatively short duration of the ICCP treatment. The loading capacities of the columns repaired by the SS technique and the ICCP-SS technique showed greater improvement compared to the columns repaired by the ICCP treatment, and also displayed greater compression capacity than the reference 
column CO. In practice, the common service life of RC structures is generally 50-70 years, or even longer than 100 years in many cases, which is much longer than the accelerated corrosion and the ICCP procedure in this study (i.e. equivalent to around 4 months for the small current density protection case and 13 months for the large current density protection case). Even in this short testing period, the ICCP-SS technique has shown its superiority over either the ICCP or the SS techniques; the ICCP-SS technique will be more beneficial in real applications in operations of longer duration.

\subsection{Comparison with design codes}

The ultimate compression capacities obtained from the test $\left(N_{\exp }\right)$ are now compared with the nominal compression design strengths predicted by the Code for design of strengthening concrete structures GB 50367-2013 (2013) $\left(N_{\mathrm{GB}}\right)$, the Guide for the Design and Construction of Externally Bonded FRP Systems for Strengthening Concrete Structures ACI440.2R - 08 (2002) $\left(N_{\mathrm{ACI}}\right)$, the ISIS Design Manual No. 4: Strengthening reinforcing concrete structures with externally-bonded fiber reinforced polymers (2001) ( $N_{\text {ISIS }}$ ), and the Technical Report on the Design and Use of Externally bonded FRP reinforcement for RC structures $(2001)\left(N_{f i b}\right)$. The design formulas of different design codes are presented in Table 6 . The comparisons were undertaken using the measured material geometries and properties, and setting all safety factors to unity. The comparisons of all specimens are presented in Fig. 10, and summarized in Table 7. The compression resistance of columns basically consists of three parts: the strength of concrete, carbon fiber mesh and re-bars.

The Chinese GB 50367 (2013) $\left(N_{\mathrm{GB}}\right)$ generally provides conservative predictions 
compared to the resistance of the stub columns obtained from tests (mean value of $N_{\text {exp }} / N_{\mathrm{GB}}=1.19$ and the coefficient of variation $\left.(\mathrm{COV})=0.086\right)$. The fib code $(2001)$ provides a mean value of 1.15 with a corresponding COV of 0.089 for the experimentalto-predicted compression loading ratios $N_{\text {exp }} / N_{\text {fib. }}$ Similarly, the ACI code (2002) has a mean value of $N_{\exp } / N_{\mathrm{ACI}}$ of 1.20 and a COV of 0.088 . The predictions by the Canadian ISIS code (2001) also underestimate the compression capacity of the tested columns with a mean value of $N_{\text {exp }} / N_{\text {ISIS }}$ of 1.12 and a COV of 0.104 . Predictions for three of the four design codes produced a similar scatter level, the exception being the ISIS code. Results also show that the four design codes are all conservative compared to the newly generated experimental results. The calculation of the loading capacity specified in these codes follows a similar approach, a combination of the compression resistance provided by the confined concrete and the longitudinal re-bars. The main difference between these calculation methods is the prediction of the ultimate strength of the confined concrete. The conservativeness of these four design codes could be largely attributed to the following two reasons.

The first reason could be an underestimation of the confinement effect of the carbon fiber mesh and the bonding performance of the cementitious material. The ICCP treatment might cause the degradation of the anodic surface (Zhu et al., 2017), which is the bond between the confining jacket and the $\mathrm{RC}$ column, resulting in more uniform strain development in the confining jacket. The better bonding may cause local strain concentration, resulting in an earlier carbon fiber mesh fracture. Thus, the poorer bonding may delay the fiber fracture, resulting in the better confinement effect. This 
explanation can also be proven by the test data. The effective strains of carbon fiber mesh measured at ultimate loads (i.e., $\varepsilon_{\text {fe }}=0.0134$ and 0.0051 for CO-C-F1-IL and COC-F1-IL-R) are presented in Table 5, while the strains of carbon fiber used in the predictions specified in different design codes (i.e. $\varepsilon_{\mathrm{fe}}=0.0035$ and 0.004 for GB 50367 (2013) and ACI (2002) are shown in Table 7. The differences between the effective strains of carbon fiber mesh obtained from tests and codified in design codes show that the design codes have underestimated the effective hoop strain and confinement effect achieved by the carbon-fabric reinforced cementitious matrix (C-FRCM) composite jacket due to the anodic polarization effect caused by the ICCP treatment. By using the measured effective strains of the confining jacket in the predictions for CO-C-F1-IL and CO-C-F1-IL-R, the predicted strengths were found to be closer to the test results (see Table 8). Therefore, this indicates that the fracture criteria and effectiveness prediction in the design codes are not precise for this studied case.

The second reason could be related to the nonlinear behavior of the jacketing carbon-fabric reinforced cementitious matrix (C-FRCM) composite. The strain distribution of carbon fiber mesh in C-FRCM depends on the bonding property at the interface between the carbon fiber mesh and the surrounding cementitious material, as well as at the interface between the cementitious material and the substrate concrete column. However, the current confining models in the design codes were proposed and calibrated based on carbon fiber sheets using epoxy resin, which is different from the stiffness and confining behavior of a C-FRCM jacket. The stiffness of carbon fiber sheets using epoxy resin increases linearly, while that of a C-FRCM jacket increases 
nonlinearly. It is well known that the constant for the hoop stress term in the case of a steel jacket, which would yield, is different from the case of a CFRP-epoxy jacket, which has no yielding point. Similarly, the empirical constants for the hoop stress term in the codified prediction equations of the confined concrete strength, such as $k_{\mathrm{c}}$ in GB50367, $\psi_{\mathrm{f}} 3.3 k_{\mathrm{a}}$ in ACI440.2, $\alpha_{\mathrm{pc}}$ in ISIS, as well as the constant values of 2.254, 7.94, 2, and 1.254 in fib, are not appropriate for our studied case with the C-FRCM jacket and ICCP treatment (Triantafillou et al., 2006). These empirical constant terms might be greater in the C-FRCM jacket with ICCP treatment because of the nonlinearity of the C-FRCM jacket after the first crack occurs (Di Ludovico et al., 2010); thus, the existing prediction equations have underestimated the confined concrete strength. However, the modification of these values needs much more careful investigation and extensive test/numerical data. The reliable values for these terms cannot be propose based at the moment, but it will be one of the key tasks in the future work.

To summarize, the underestimation of the effectiveness and stiffness of the confining jacket (C-FRCM composite) might be the two key reasons leading to the conservative predictions of the compression loading capacity of repaired RC columns using the ICCP-SS technique. Further investigation of the effective ultimate strain and the stress-strain relationship of the proposed carbon-fabric reinforced cementitious matrix (C-FRCM) composite jacket after long-term ICCP treatment are still needed in the future work.

\section{Conclusions}


This study tested 10 axially loaded RC columns with/without carbon fiber mesh external confinement in order to investigate the performance of columns repaired by ICCP, SS or ICCP-SS techniques. The experimental program included the accelerated corrosion procedure, the ICCP operation, and the compression tests. Carbon fiber mesh acted as both the anode and strengthening material in the impressed current cathodic protection - structural strengthening (ICCP-SS) system. Experimental results showed improvement in the strength capacity as the result of ICCP-SS application. The applied current density of $20 \mathrm{~mA} / \mathrm{m}^{2}$ was found to be effective for cathodic protection. In addition, a comparison between test results and predictions by the GB, ACI, ISIS, and fib design guidelines were made. All design codes were found to be slightly conservative. The poorer bond of C-FRCM may be the reason of underestimation of the code formulas, which were obtained from FRP jacket. The exiting design codes for RC columns repaired by the ICCP-SS technique should consider the level of corrosion and the duration of ICCP. The application of the ICCP-SS technique will provide a solution to sea-sand sea-water reinforced concrete structures. In the future work, more efforts are needed to optimize the applied current density and the amount of strengthening material, and a longer period for the corrosion and ICCP should be considered to determine the durability performance of RC structures.

\section{Acknowledgements}

The research work described in this paper was supported by the National Natural Science Foundation China (Project No.: 51538007, 51478269, 51508336) and the 
Natural Science Foundation of SZU (grant no. 2016068).

\section{Notations}

$A_{\text {cor }} \quad=$ The area of confined concrete;

$A_{\mathrm{g}} \quad=$ Column gross cross-sectional area;

$A_{\mathrm{s}} \quad=$ Total area of longitudinal steel reinforcement;

$A_{\mathrm{so}}^{\prime}, A_{\mathrm{st}}=$ The area of longitudinal re-bars;

$D, D_{\mathrm{g}} \quad=$ Gross column diameter;

$d_{\mathrm{j}} \quad=$ Diameter of FRP jacket;

$E_{\mathrm{f}}, E_{\mathrm{j}} \quad=$ Elastic modulus of FRP;

$f_{\mathrm{c}}^{\prime}, f_{\mathrm{co}}=$ Unconfined concrete compressive strength;

$f_{\mathrm{cc}}, f_{\mathrm{cc}}^{\prime}=$ Compressive strength of confined concrete;

$f_{\text {frpu }} \quad=$ Ultimate strength of FRP;

$f_{1,}$ ol $\quad=$ Maximum confining stress due to FRP;

$f_{\text {lfrp }} \quad=$ Lateral confining pressure exerted by the FRP at ultimate;

$f_{\mathrm{y}} \quad=$ Yield strength of steel re-bars

$f_{\text {yo }}^{\prime} \quad=$ Yield stress of re-bars;

$k_{\mathrm{a}} \quad=$ Efficiency factor for FRP reinforcement in determination of $f_{c c}^{\prime}$;

$k_{\mathrm{c}} \quad=$ Coefficient considering effective confinement

$k_{\mathrm{e}} \quad=$ Strength reduction factor;

$N_{\mathrm{ACI}}=$ Nominal compressive strength predicted from ACI440.2R -08

$N_{\mathrm{b}}, n, n_{\mathrm{f}}=$ Number of layers of FRP;

$N_{\text {design }}=$ Design strengths of columns 
$N_{\exp } \quad=$ Experimental strengths of columns

$N_{f i b} \quad=$ Nominal compressive strength predicted from fib

$N_{G B} \quad=$ Nominal compressive strength predicted from GB50367-2013;

$N_{\text {ISIS }} \quad=$ Nominal compressive strength predicted from ISIS;

$t_{\mathrm{f}} \quad=$ Nominal thickness of one ply of FRP;

$t_{\mathrm{frp}}, t_{\mathrm{j}}=$ Total thickness of FRP;

$\alpha_{1} \quad=$ Ratio of average stress in rectangular compression block to the specified concrete compressive strength

$\alpha_{\mathrm{pc}} \quad=$ Performance coefficient for FRP confined concrete;

$\beta_{\mathrm{c}} \quad=$ Coefficient considering concrete strength

$\varepsilon_{\mathrm{fe}}, \varepsilon_{\mathrm{j}}=$ Effective strain level in FRP reinforcement attained at failure;

$\phi \quad=$ Strength reduction factor

$\phi_{\mathrm{c}} \quad=$ Resistance factor for concrete

$\phi_{\text {frp }} \quad=$ Resistance factor for FRP;

$\phi_{\mathrm{s}} \quad=$ Resistance factor for steel reinforcing bars

$\rho_{\mathrm{f}}, \rho_{\mathrm{j}}=$ Volumetric ratio of FRP jacket in circular columns;

$\omega_{\mathrm{w}} \quad=$ Volumetric confinement ratio;

$\psi_{\mathrm{f}} \quad=$ FRP strength reduction factor;

\section{References}

ACI (2002), Guide for the design and construction of externally bonded FRP systems for strengthening concrete structures, ACI 440.2R-08, American Concrete Institute, United States. Ahmad S (2003). "Reinforcement corrosion in concrete structures, its monitoring and service life prediction—a review", Cement and Concrete Composites, 25(4-5):459-71. 
ASTM (2009). Standard Test Method for Half-Cell Potentials of Uncoated Reinforcing Steel in Concrete, $C$ 876-09, United States.

ASTM (2017). Standard test methods for properties of continuous filament carbon and graphite fiber tows, D4018-17, United States.

Audenaert, K., Toutanji, H. and Matthys, S. (2005). "Axial Load Behavior of Large-Scale Columns Confined with Fiber-Reinforced Polymer Composites", ACI Structural Journal, 102(2):258-267.

Basalo, F. D. C., Matta, F. and Nanni, A. (2012). "Fiber reinforced cement-based composite system for concrete confinement”. Construction \& Building Materials, 32(7):55-65.

Bennett, J. E., Bushman, J. B., Clear, K. C., Kamp, R. and Swiat, W. J. (1993). Cathodic protection of concrete bridges: a manual of practice. SHRP-S-372, National Research Council, Washington DC.

Chai Y. H., Priestley, M. J. N. and Seible, F. (1991). Flexural retrofit of circular reinforced concrete bridge columns by steel jacketing: experimental studies, RTA-59G267, Federal Highway Administration.

China Academy of Building Research (2015), Concrete Structural Design Code GB50010-2010, China Architecture \& Building Press.

Clemeña, G. G. and Jackson, D. R. (2000). Final report cathodic protection of concrete bridge decks using titanium-mesh anodes. VTRC 00-R14, Virginia Department of Transportation, Virginia.

Di Ludovico, M.; Prota, A.; and Manfredi, G., (2010), "Structural upgrade using basalt fibers for concrete confinement", Journal of Composites for Construction, 14( 5): 541-552.

Eid, R. and Paultre, P. (2017). "Compressive behavior of FRP-confined reinforced concrete columns”. Engineering Structures, 132:518-530.

Fang CQ, Lundgren K, Chen LG, Zhu, C. (2004), "Corrosion influence on bond in reinforced concrete”, Cement \& Concrete Research,34:2159-67.

Fib (2001), Externally bonded FRP reinforcement for RC structures, Technical report bulletin 14, the International Federation for Structural Concrete, Switzerland.

GB50367-2013 (2013). Code for design of strengthening concrete structures, China.

Han-Seung Lee, Noguchi T, Tomosawa F. (2002), "Evaluation of the bond properties between concrete and reinforcement as a function of the degree of reinforcement corrosion", Cement \& Concrete Research 32:1313-8.

ISIS Canada (2001). ISIS Canada Design Manual No. 4: Strengthening reinforced concrete structures with externally-bonded fiber reinforced polymers, Winnipeg, Canada.

Juntanalikit P, Jirawattanasomkul T and Pimanmas A (2016). "Experimental and numerical study of strengthening non-ductile RC columns with and without lap splice by Carbon Fiber Reinforced Polymer (CFRP) jacketing”, Engineering Structures, 125:400-18. 
Khalili, H. H. and Fardis, M. N. (1982). "FRP-encased concrete as a structural material", Magazine of Concrete Research. 34(121):191-202.

Lambert, P. and MacDonald, M. (1998). Reinforced Concrete-History, Properties \& Durability. Corrosion Prevention Association.

Lambert P., Nguyen, C. V., Mangat P S, O’Flaherty, F. and Jones, G. (2015). "Dual function carbon fibre fabric strengthening and impressed current cathodic protection (ICCP) anode for reinforced concrete structures". Materials and Structures, 48(7):2157-2167.

McLeish, A. (1987). Structural assessment, manual for life cycle aspects of concrete in buildings and structures. Taywood Engineering Limited, UK.

Nguyen, C. V., Lambert, P., Mangat, P. S., O'Flaherty, F. and Jones, G. (2016). "Near-surface mounted carbon fibre rod used for combined strengthening and cathodic protection for reinforced concrete structures". Structure \& Infrastructure Engineering, 12(3):356-365.

Ombres L (2014). "Concrete confinement with a cement based high strength composite material”, Composite Structures, 109(6):294-304.

Ombres, L. and Verre, S. (2015). "Structural behaviour of fabric reinforced cementitious matrix (FRCM) strengthened concrete columns under eccentric loading”. Composites Part B Engineering, 75:235-249.

Özcan, O., Binici, B. and Özcebe, G. (2010). "Investigation of FRP strengthening design rules for insufficient RC columns”. Clinical \& Experimental Immunology, 21(4):5219-39.

Revie, R. W. and Uhlig, H. H. (1963). Corrosion and corrosion control: an introduction to corrosion science and engineering. Wiley, 7(3): 98.

Rodriguez, J., Ortega, L. and Casal, J. (1994). "Corrosion of reinforcing bars and service life of reinforced concrete structures: corrosion and bond deterioration". International conference on concrete across borders, pp. 315-26, Odense, Denmark.

Silva, M. A. G. (2011), "Behavior of square and circular columns strengthened with aramidic or carbon fibers". Construction \& Building Materials, 2011, 25(8):3222-3228.

Sun, H., Wei, L., Zhu, M, Han, N. and Zhu, J. H.(2016). "Corrosion behavior of carbon fiber reinforced polymer anode in simulated impressed current cathodic protection system with $3 \%$ $\mathrm{NaCl}$ solution", Construction \& Building Materials, 112:538-546.

The Concrete Society (2001). Cathodic protection of steel in concrete. Technical Report 73.

Triantafillou, T. C., Papanicolaou, C. G., Zissimopoulos, P., and Laourdekis, T. (2006), "Concrete confinement with textile-reinforced mortar jackets." ACI Structural Journal, 103(1): $28-37$.

Zhu, J. H., Zhu, M. C., Han, N. X., Liu, W. and Xing F. (2014a). "Electrical and mechanical performance of carbon fiber-reinforced polymer used as the impressed current anode material". Materials. 7(8):5438-53.

Zhu, J. H., Zhu, M. C., Han, N. X., Xing, F., Liu, W. and Bertolini, L. (2014b). "Behavior of 
CFRP plate in simulated ICCP system of concrete structures", Proceeding of the $4^{\text {th }}$ International Conference on the Durability of Concrete Structures, pp. 363-368, 24-26 July 2014, Purdue University, USA.

Zhu, J. H., Guo, G., Wei, L., Zhu, M. and Chen, X.(2016a). "Dual function behavior of carbon fiber-reinforced polymer in simulated pore solution". Materials, 9(2):103.

Zhu, J. H., Wei, L., Guo, G. and Zhu, A. (2016b). "Mechanical and electrochemical performance of carbon fiber reinforced polymer in oxygen evolution environment". Polymers. 8(11):393.

Zhu, J. H., Wei L. L., Moahmoud, H., Redaelli, E., Xing F. and Bertolini, L. (2017), "Investigation on the dual-functions of CFRP in the varying chloride-contained environments". Construction and Building Materials, 151:127-137.

ZHU Ji-hua, LIN Wei-hao, CHEN Pi-yu, UEDA Tamon, XING Feng, WEI Liang-liang, ZHU Miaochang, SU Mei-ni, (2017). "The bond behavior between C-FRCM composite and concrete under the impressed current cathodic protection", Proceeding of 6th Asia-Pacific Conference on FRP in Structure. (Singapore, 19-21 July, 2017) 

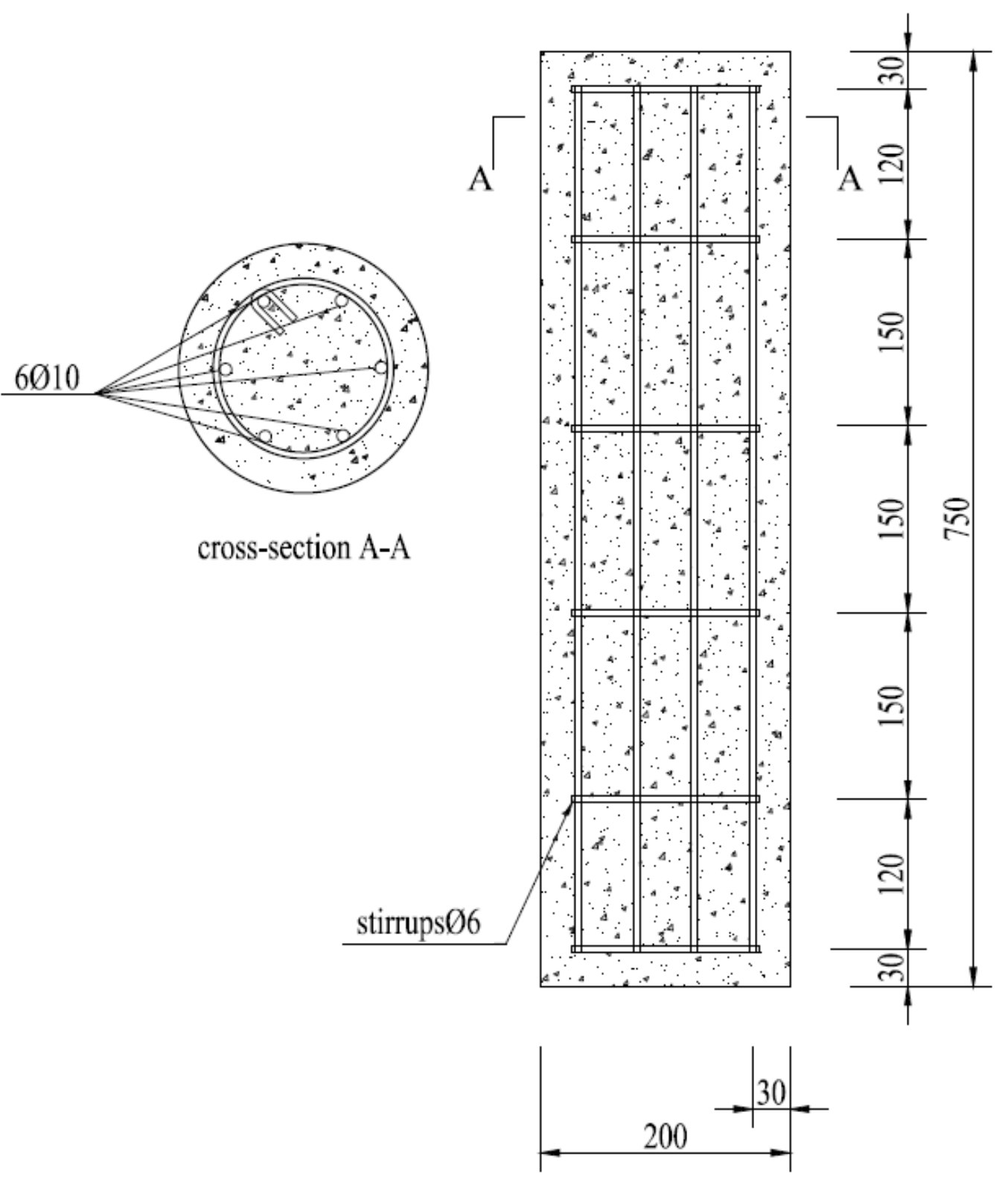

Fig. 1 Detailed dimensions of column specimens (all dimensions in $\mathrm{mm}$ ) 


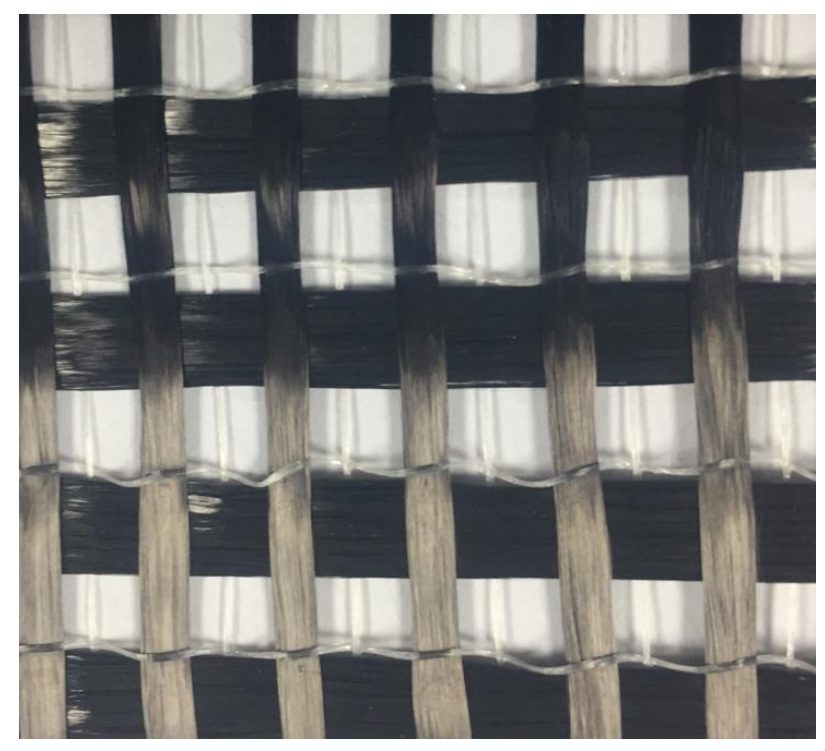

Fig. 2 A typical roll of carbon fiber mesh 


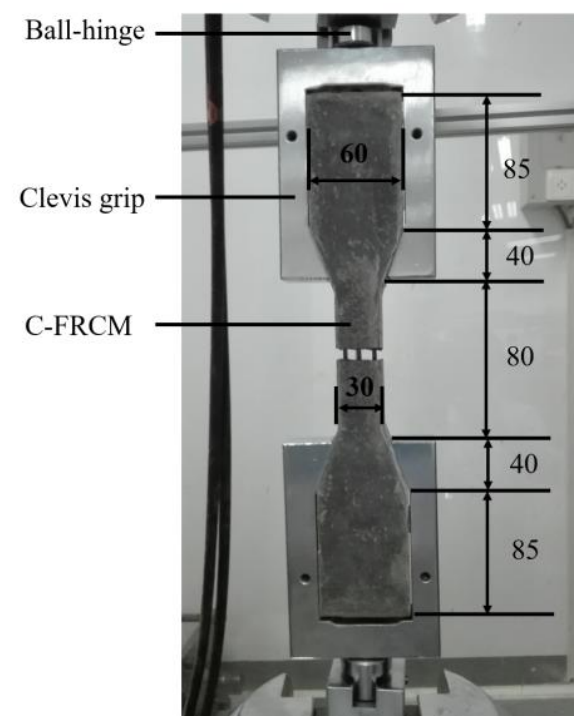

(a) Test set-up

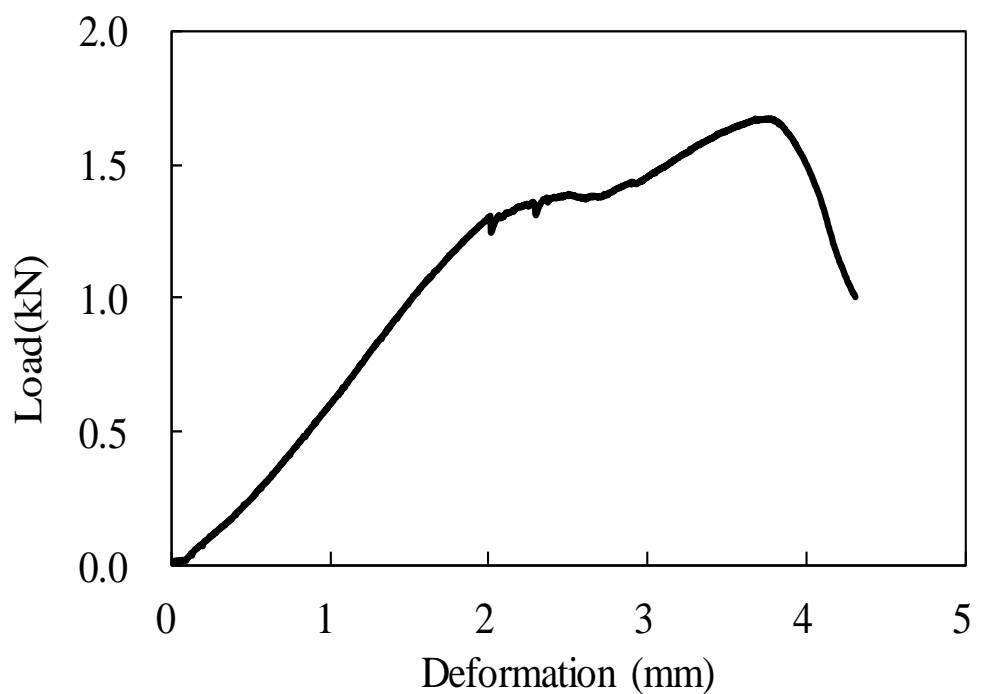

(b) Typical load-deformation curve

Fig. 3 Test set-up and a typical load-deformation curve of the C-FRCM composite 


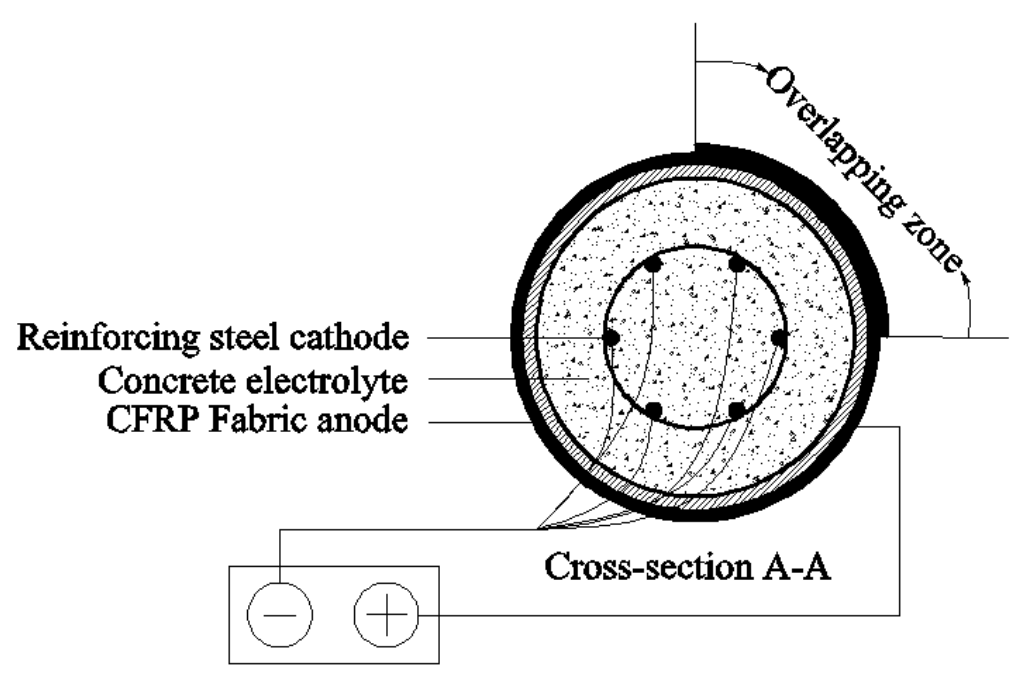

DC power supply

Fig. 4 Schematic ICCP application to the corroded reinforced concrete columns 


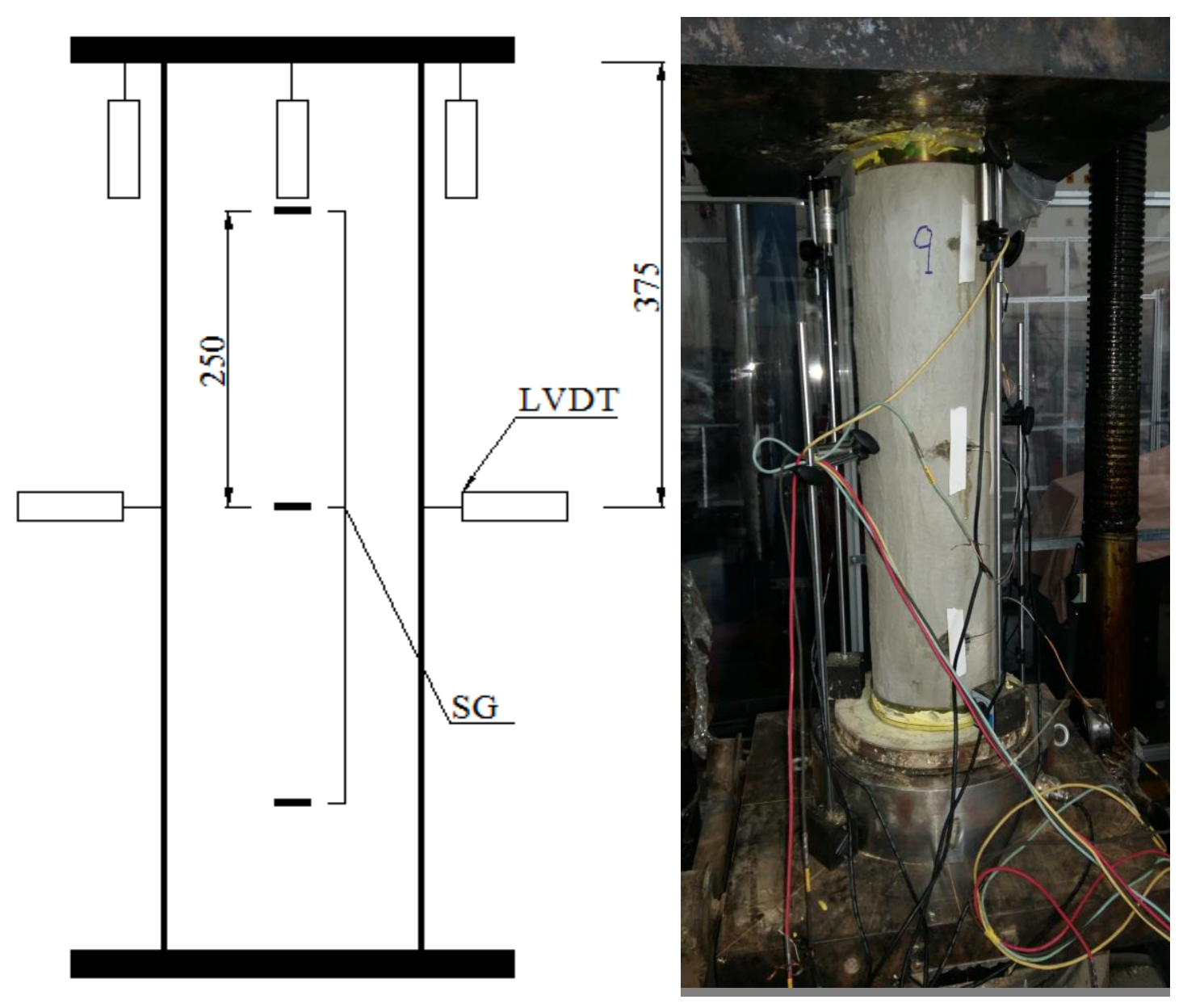

Fig. 5 Set-up of stub column tests and the arrangement of LVDT and strain gauges 


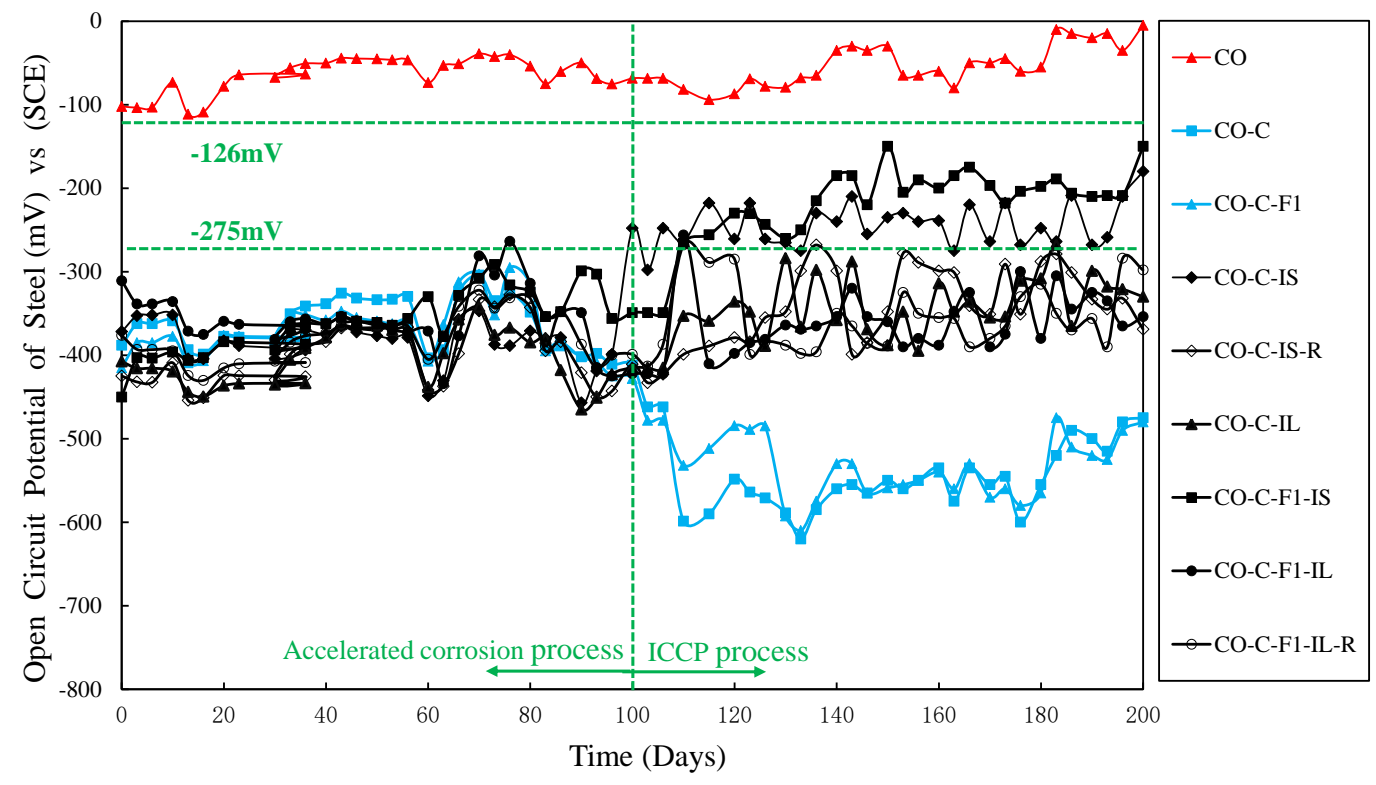

Fig. 6 Potential of re-bars using ICCP application 


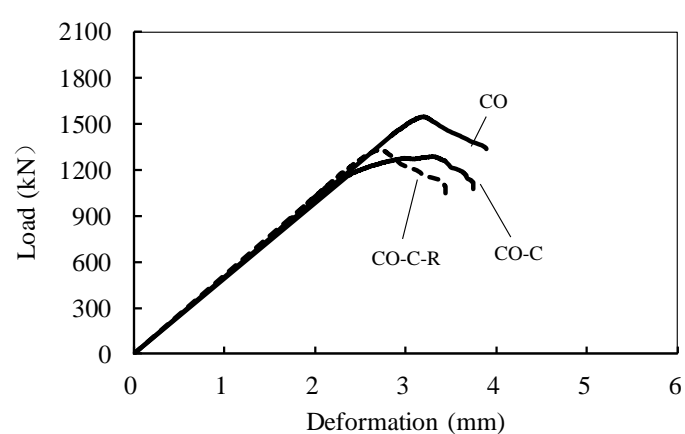

(a) Specimens without any treatment

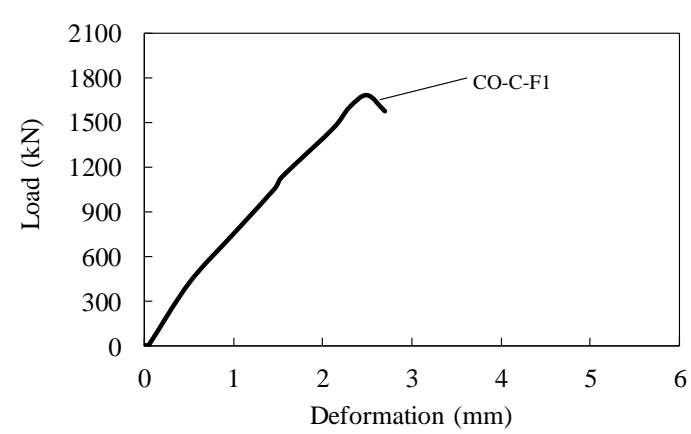

(c) Specimens repaired by SS

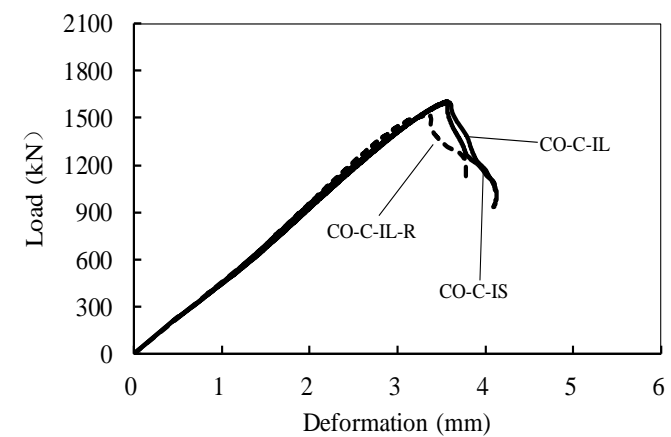

(b) Specimens protected by ICCP

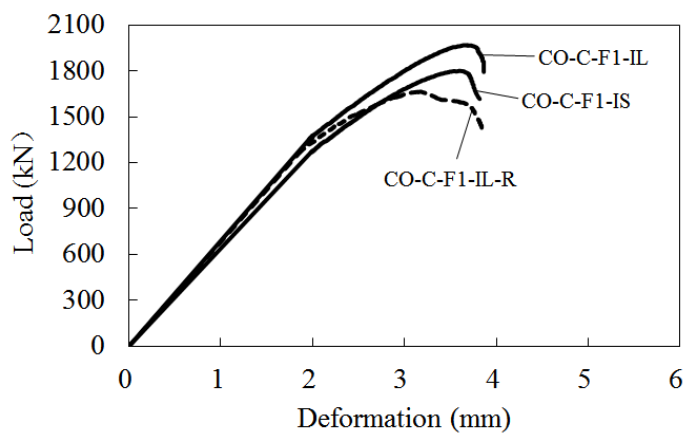

(d) Specimens protected by ICCP-SS

Figure 7: Load-deformation curves of columns 


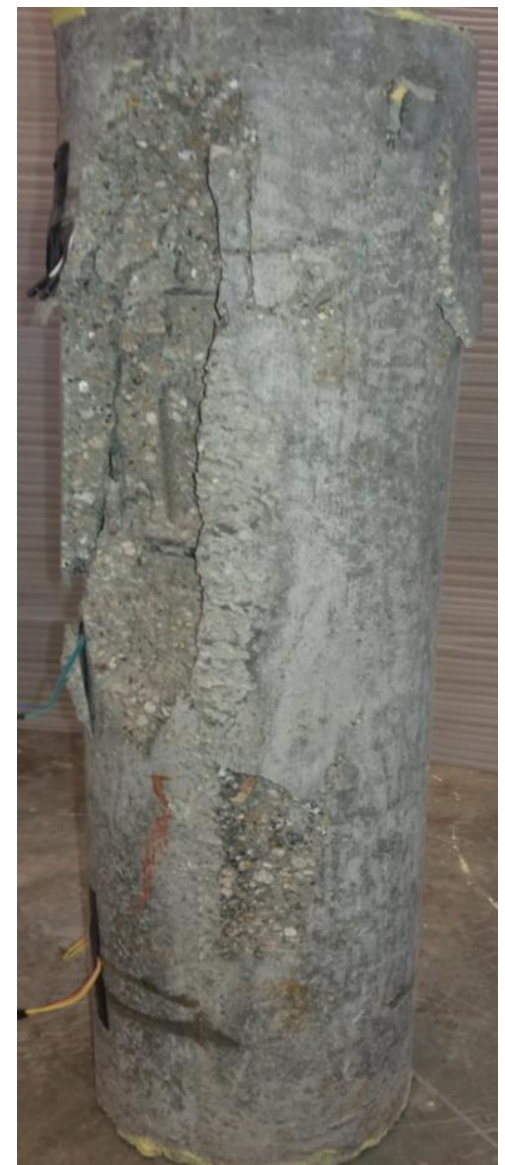

(a) Specimen without carbon fiber mesh strengthening

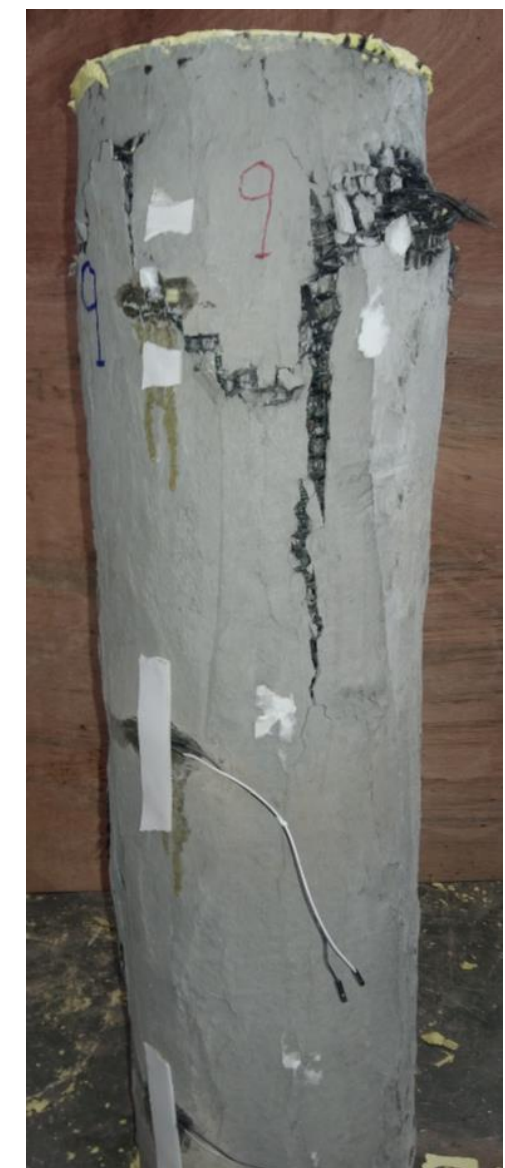

(b) Specimen with carbon fiber mesh strengthening

Fig. 8 Typical failure modes of stub column tests 

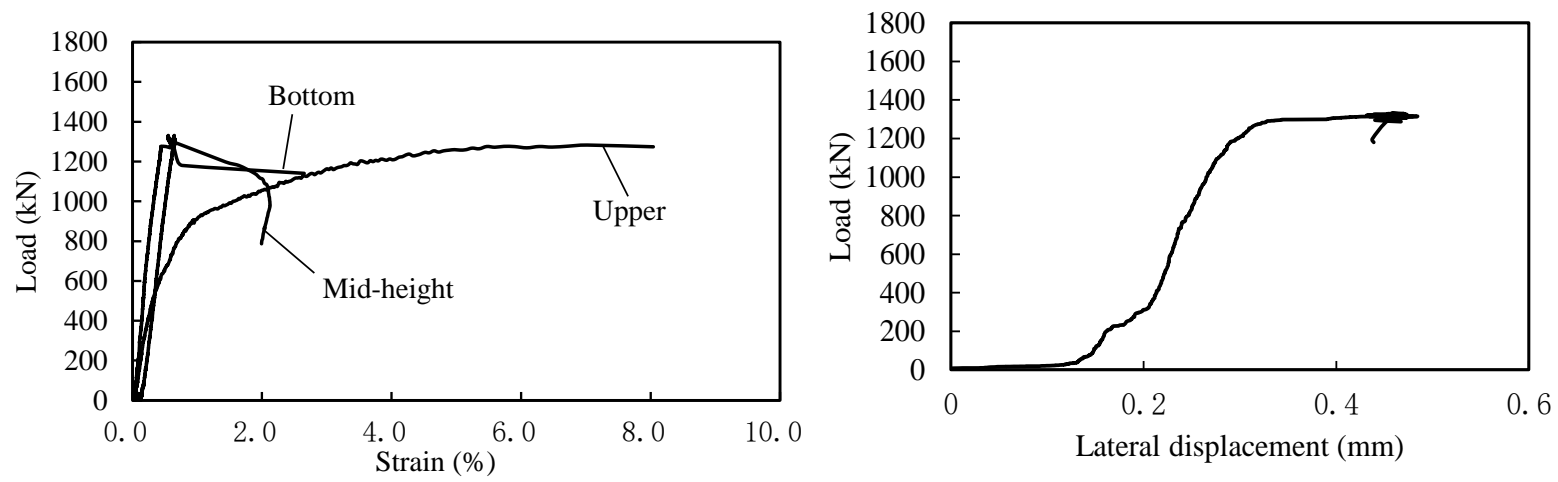

(a) Specimens without carbon fiber mesh strengthening (specimen CO-C-R)
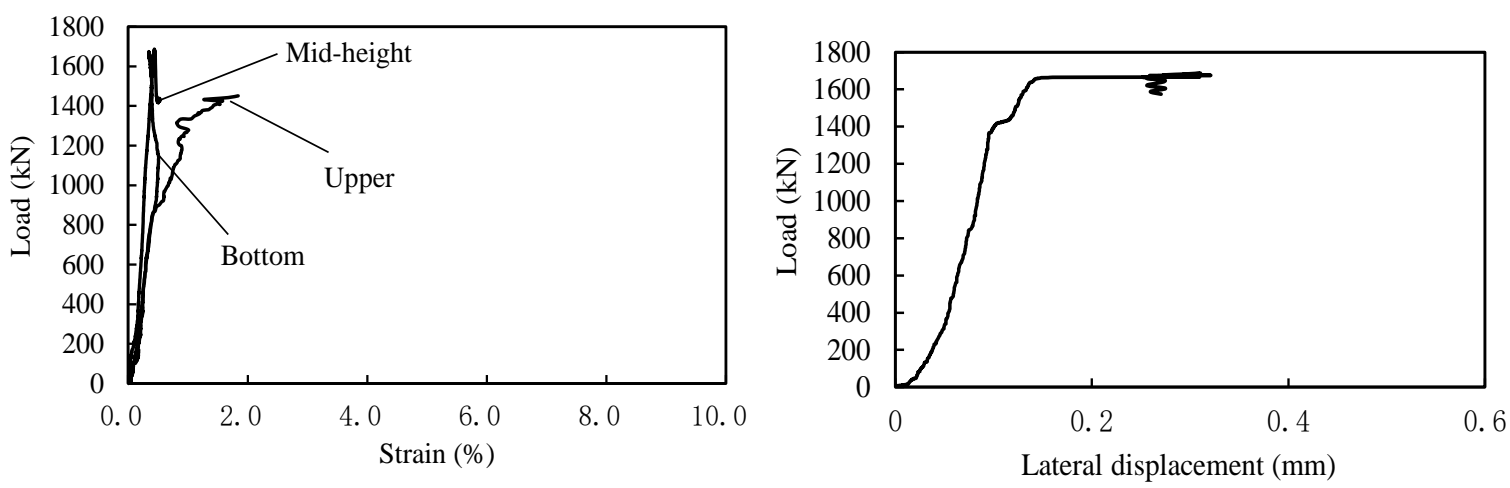

(b) Specimens with carbon fiber mesh strengthening (specimen CO-C-F1)

Fig. 9 Load - carbon fiber mesh strain and load - lateral displacement (at mid-height) curves. 


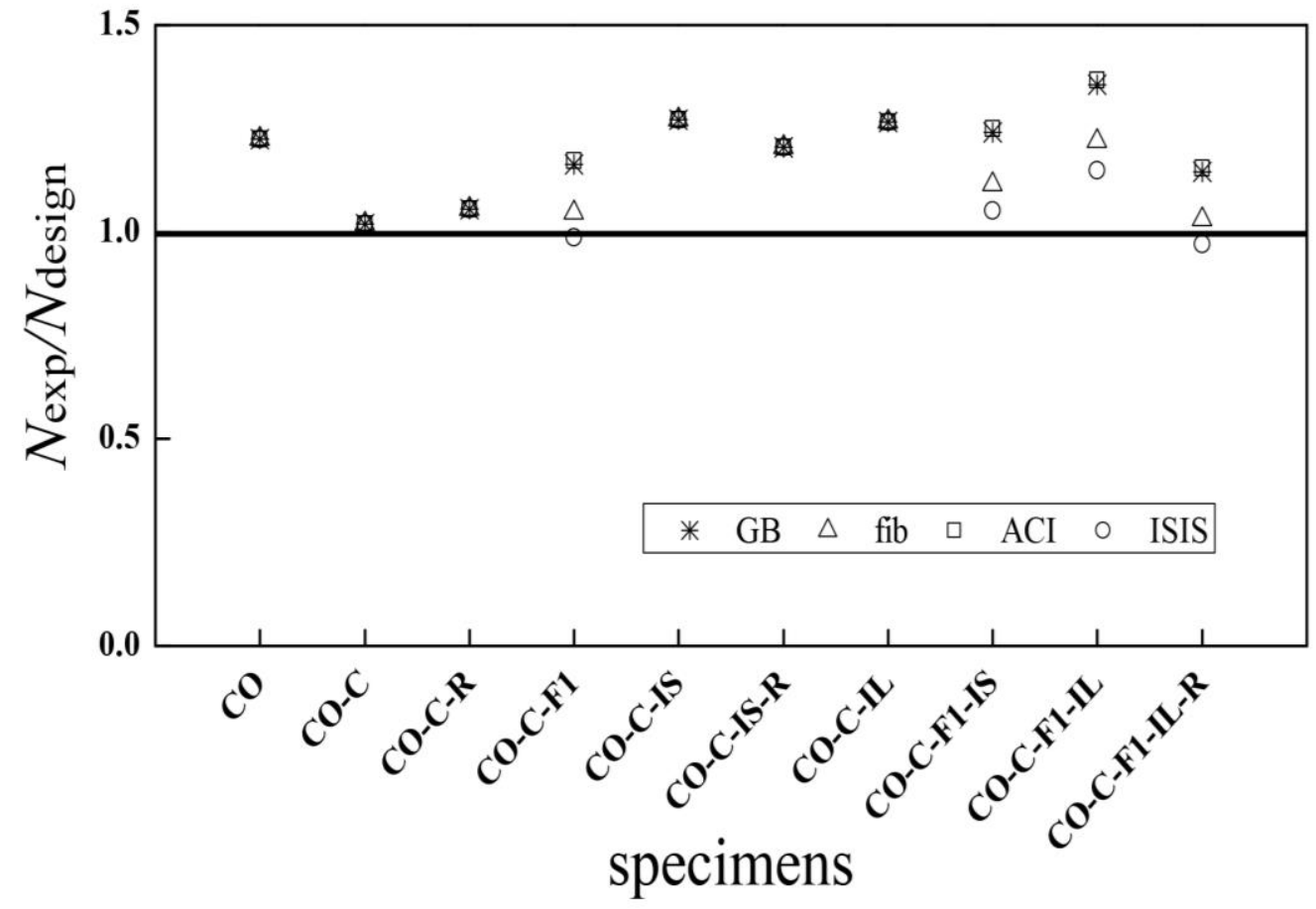

Fig. 10 Comparison between the experimental compressive capacities and the design strengths 
Table 1. Details of test program

\begin{tabular}{lccc}
\hline \multirow{2}{*}{ Specimens } & NaCl & \multicolumn{2}{c}{ Repair method } \\
\cline { 2 - 4 } & $(\%)$ & Carbon fiber mesh strengthening & ICCP \\
\hline CO & 0 & None & None \\
CO-C & 3 & None & None \\
CO-C-R & 3 & Yes & None \\
CO-C-F1 & 3 & None & None \\
CO-C-IS & 3 & None & IS \\
CO-C-IS-R & 3 & None & IS \\
CO-C-IL & 3 & Yes & IL \\
CO-C-F1-IS & 3 & Yes & IS \\
CO-C-F1-IL & 3 & Yes & IL \\
CO-C-F1-IL-R & 3 & IL \\
\hline
\end{tabular}

Note: CO stands for column, $\mathrm{C}$ means the column was subjected to corrosion, F1 means the column was strengthened by one layer of FRP; IS and IL represent applied current densities of $26 \mathrm{~mA} / \mathrm{m}^{2}$ and $80 \mathrm{~mA} / \mathrm{m}^{2}$ respectively; $R$ means repeated tests. 
Table 2. Ingredients of concrete mix

\begin{tabular}{ccccc}
\hline $\begin{array}{c}\text { Cement } \\
(\mathrm{kg})\end{array}$ & $\begin{array}{c}\text { Fine } \\
\text { aggregate } \\
(\mathrm{kg})\end{array}$ & $\begin{array}{c}\text { Coarse } \\
\text { aggregate } \\
(\mathrm{kg})\end{array}$ & $\begin{array}{c}\text { Water } \\
(\mathrm{kg})\end{array}$ & $\begin{array}{c}\text { Superplasticizer } \\
(\mathrm{ml})\end{array}$ \\
\hline 1 & 1.29 & 2.88 & 0.39 & 0.01 \\
\hline
\end{tabular}


Table 3. Ingredients for the cementitious material

Composition

By the mass of cement

$(\%)$

Cement

100

Silica fume

11.11

Polymer

22.22

Defoamer

0.53

Superplasticizer

1.2

Water

50

Carbon fiber

1 
Table 4. Material properties of concrete, re-bars, carbon fiber net and cementitious material

\begin{tabular}{|c|c|c|c|c|c|c|c|}
\hline Material & $\begin{array}{l}\text { Thickness/ } \\
\text { Diameter } \\
(\mathrm{mm})\end{array}$ & $\begin{array}{l}\text { Yield } \\
\text { stress } \\
(\mathrm{MPa})\end{array}$ & $\begin{array}{c}\text { Tensile } \\
\text { strength } \\
\text { (MPa) }\end{array}$ & $\begin{array}{c}\text { Flexure } \\
\text { strength } \\
(\mathrm{MPa})\end{array}$ & $\begin{array}{l}\text { Compression } \\
\text { strength } \\
(\mathrm{MPa})\end{array}$ & $\begin{array}{c}\text { Young's } \\
\text { Modulus } \\
(\mathrm{GPa})\end{array}$ & $\begin{array}{c}\text { Fracture } \\
\text { strain } \\
(\%)\end{array}$ \\
\hline Concrete & --- & --- & --- & --- & $53.0^{\wedge}$ & --- & --- \\
\hline $\begin{array}{c}\text { Re-bars } \\
\text { (HRB400) }\end{array}$ & 6 & 536 & 638 & --- & --- & 198 & --- \\
\hline $\begin{array}{c}\text { Re-bars } \\
\text { (HRB400) }\end{array}$ & 10 & 380 & 545 & --- & --- & 200 & --- \\
\hline $\begin{array}{c}\text { Carbon fiber } \\
\text { mesh }\end{array}$ & 0.207 & --- & 3519 & --- & --- & 223 & 1.58 \\
\hline $\begin{array}{c}\text { Cementitious } \\
\text { material }\end{array}$ & --- & --- & --- & 21 & 32.8 & --- & --- \\
\hline
\end{tabular}

Note: $\wedge$ Test results are from concrete cubic tests 
Table 5. Compression capacity and deformation of columns

\begin{tabular}{|c|c|c|c|c|c|}
\hline Columns & $\begin{array}{c}\text { Ultimate } \\
\text { load } \\
(\mathrm{kN})\end{array}$ & $\begin{array}{l}\text { Ultimate } \\
\text { deformation } \\
\quad(\mathrm{mm})\end{array}$ & $\begin{array}{l}\text { Hoop strain of } \\
\text { carbon fiber } \\
\text { mesh measured } \\
\text { at ultimate loads }\end{array}$ & $\begin{array}{l}\text { Increase in strength } \\
\text { compared to control } \\
\text { column } \\
(\mathrm{CO}) \\
(\text { load }=1545 \mathrm{kN}) \\
(\%)\end{array}$ & $\begin{array}{l}\text { Increase in strength } \\
\text { compared to } \\
\text { corroded columns } \\
\text { (CO-C and CO-C-R) } \\
\text { (average load = } \\
1309 \mathrm{kN}) \\
(\%)\end{array}$ \\
\hline $\mathrm{CO}$ & 1545 & 1.1 & --- & --- & 18.0 \\
\hline $\mathrm{CO}-\mathrm{C}$ & 1286 & 1.9 & --- & -16.8 & --- \\
\hline CO-C-R & 1331 & 1.9 & --- & -13.0 & --- \\
\hline CO-C-F1 & 1687 & 2.5 & $0.0027 *$ & 9.2 & 28.9 \\
\hline CO-C-IS & 1605 & 2 & --- & 3.9 & 22.6 \\
\hline CO-C-IS-R & 1520 & 1.7 & --- & -1.6 & 16.1 \\
\hline CO-C-IL & 1597 & 1.7 & --- & 3.4 & 22.0 \\
\hline CO-C-F1-IS & 1801 & 3.7 & $0.0018^{*}$ & 16.6 & 37.6 \\
\hline CO-C-F1-IL & 1969 & 2.7 & 0.0134 & 27.4 & 50.4 \\
\hline CO-C-F1-IL-R & 1664 & 2 & 0.0051 & 7.7 & 27.0 \\
\hline
\end{tabular}

* These data were obtained when the strain gauges failed, before the ultimate loads were reached. 
Table 6: Design approaches in different design codes

\begin{tabular}{|c|c|c|c|c|}
\hline Codes & $\begin{array}{l}\text { GB50367 } \\
(2013)\end{array}$ & $\begin{array}{l}\text { ACI } 440.2 \mathrm{R}-08 \\
\quad(2002)\end{array}$ & $\begin{array}{c}\text { ISIS } \\
(2001)\end{array}$ & $\begin{array}{c}\text { fib } \\
(2001)\end{array}$ \\
\hline $\begin{array}{l}\text { Design } \\
\text { formula }\end{array}$ & $N_{\mathrm{GB}}=\left[\left(f_{c o}+4 \sigma_{l}\right) A_{c o r}+f_{y o}^{\prime} A_{s o}^{\prime}\right]$ & $N_{A C I}=0.85\left[0.85 f_{c c}^{\prime}\left(A_{g}-A_{s t}\right)+f_{y} A_{s t}\right]$ & $N_{I S I S}=\alpha_{1} f_{c c}^{\prime}\left(A_{g}-A_{s}\right)+f_{y} A_{s}$ & $N_{f i b}=f_{c c}\left(A_{g}-A_{s}\right)+f_{y} A_{s}$ \\
\hline Notations & $\begin{array}{l}A_{c o r} \text { is the area of confined concrete; } \\
A_{s o}^{\prime} \text { is the area of longitudinal re-bars; } \\
D \text { is diameter of the column; } \\
E_{f} \text { is the elastic modulus of FRP; } \\
f_{c o} \text { is the axial compression strength } \\
\text { of unconfined concrete; } \\
f_{y o}^{\prime} \text { is the yield stress of re-bars; } \\
k_{c}=0.95 \text { is the coefficient considering } \\
\text { effective confinement; } \\
n_{f} \text { is the number of FRP layers; } \\
t_{f} \text { is the thickness of one ply of FRP } \\
\text { reinforcement; } \\
\sigma_{l}=0.5 \beta_{c} k_{c} \rho_{f} E_{f} \varepsilon_{f e} \text {, is the } \\
\text { effective confined stress; } \\
\beta_{c} \text { is the coefficient considering } \\
\text { concrete strength; } \\
\varepsilon_{f e}=0.0035, \text { is the effective strain } \\
\text { level in FRP reinforcement attained at } \\
\text { failure; } \\
\rho_{f}=\frac{4 n_{f} t_{f}}{D}, \text { is the volumetric } \\
\text { confinement ratio }\end{array}$ & $\begin{array}{l}A_{g} \text { is the gross area of concrete section; } \\
A_{s t} \text { is the total area of longitudinal } \\
\text { reinforcement; } \\
D \text { is diameter of the column; } \\
E_{f} \text { is the Modulus of FRP; } \\
f_{c c}^{\prime}=f_{c}^{\prime}+\psi_{f} 3.3 k_{a} f_{l} \text {, is compressive } \\
\text { strength of confined concrete; } \\
f_{c}^{\prime} \text { is the axial compression strength of } \\
\text { unconfined concrete; } \\
f_{l}=\frac{2 E_{f} n t_{f} \varepsilon_{f e}}{D}, \text { is maximum confining } \\
\text { pressure due to FRP jacket; } \\
f_{y} \text { is specified yield strength of } \\
\text { nonprestressed steel reinforcement. } \\
k_{a} \text { is efficiency factor for FRP reinforcement } \\
\text { in determination of } f_{c c}^{\prime} \text {; } \\
n \text { is the number of plies of FRP } \\
\text { reinforcement; } \\
t_{f} \text { is nominal thickness of one ply of FRP } \\
\text { reinforcement; } \\
\varepsilon_{f e}=0.004 \leq k \varepsilon_{f u}, \text { is the effective strain } \\
\text { level in FRP reinforcement attained at failure; } \\
\psi_{f} \text { is FRP strength reduction factor; }\end{array}$ & $\begin{array}{l}A_{g} \text { is cross-sectional area; } \\
A_{s} \text { is area of longitudinal reinforcing steel; } \\
D_{g} \text { is gross concrete diameter; } \\
f_{c}^{\prime} \text { is the unconfined concrete compressive } \\
\text { strength; } \\
f_{c c}^{\prime}=f_{c}^{\prime}\left(1+\alpha_{p c} \omega_{w}\right) \text {, is the ultimate } \\
\text { strength of the confined concrete; } \\
f_{f r p u} \text { is ultimate strength of FRP; } \\
f_{l f r p}=\frac{2 N_{b} \phi_{f r p} f_{f r p u} t_{f r p}}{D_{g}}, \text { is lateral } \\
\text { confining pressure exerted by the FRP at } \\
\text { ultimate; } \\
f_{y} \text { is yield stress of re-bars; } \\
N_{b} \text { is number of layers of FRP; } \\
t_{f r p} \text { is total thickness of FRP; } \\
\alpha_{1} \text { is ratio of average stress in rectangular } \\
\text { compression block to the specified concrete } \\
\text { compressive strength; } \\
\alpha_{p c}=1.0, \text { is the performance coefficient; } \\
\omega_{w}=\frac{2 f_{l f r p}}{\phi_{c} f_{c}^{\prime}}, \text { is volumetric confinement } \\
\text { ratio; } \\
\phi_{c} \text { is resistance factor for concrete; } \\
\phi_{f r p} \text { is resistance factor for carbon FRP; }\end{array}$ & $\begin{array}{l}A_{g} \text { is gross area of concrete; } \\
A_{s} \text { is total area of longitudinal steel } \\
\text { reinforcement; } \\
d_{j} \text { is diameter of FRP jacket; } \\
E_{j} \text { is modulus of FRP jacket; } \\
f_{c c}= \\
f_{c o}\left(2.254 \sqrt{1+7.94 \frac{f_{l}}{f_{c o}}}-2 \frac{f_{l}}{f_{c o}}-1.254\right), \\
\text { is confined concrete strength; } \\
f_{c o} \text { is unconfined concrete strength; } \\
f_{l}=\frac{1}{2} \rho_{j} E_{j} \varepsilon_{j u} \text {, is the maximum } \\
\text { confining stress; } \\
f_{y} \text { is the steel yield strength. } \\
t_{j} \text { is thickness of FRP jacket; } \\
\varepsilon_{j u} \text { is circumferential strain in FRP } \\
\text { jacket. (Since no recommended value } \\
\text { is specified in fib, this parameter is } \\
\text { taken as } 0.004 \text { as recommended in } \\
\text { ACI); } \\
\rho_{j}=\frac{4 t_{j}}{d_{j}} \text { is volumetric ratio of FRP } \\
\text { jacket in circular columns. }\end{array}$ \\
\hline
\end{tabular}


Table 7. Summary of comparisons between compressive bearing capacity test results and design strengths

\begin{tabular}{lcccc}
\hline Specimen & $N_{\text {exp }} / N_{\text {GB }}$ & $N_{\text {exp }} / N_{\text {fib }}$ & $N_{\text {exp }} / N_{\text {ACI }}$ & $N_{\text {exp }} / N_{\text {ISIS }}$ \\
\hline CO & 1.22 & 1.22 & 1.22 & 1.22 \\
CO-C & 1.02 & 1.02 & 1.02 & 1.02 \\
CO-C-R & 1.05 & 1.05 & 1.05 & 1.05 \\
CO-C-F1 & 1.16 & 1.05 & 1.17 & 0.99 \\
CO-C-IS & 1.27 & 1.27 & 1.27 & 1.27 \\
CO-C-IS-R & 1.20 & 1.20 & 1.20 & 1.20 \\
CO-C-IL & 1.27 & 1.27 & 1.27 & 1.27 \\
CO-C-F1-IS & 1.24 & 1.12 & 1.25 & 1.05 \\
CO-C-F1-IL & 1.36 & 1.22 & 1.37 & 1.15 \\
CO-C-F1-IL-R & 1.15 & 1.03 & 1.15 & 0.97 \\
\hline Mean & 1.19 & 1.15 & 1.20 & 1.12 \\
COV & 0.086 & 0.089 & 0.088 & 0.104 \\
\hline
\end{tabular}

Note:

The ultimate carbon fiber mesh strain used in the prediction is taken as 0.0035 for GB code, as specified in GB50367 (2013)

The ultimate carbon fiber mesh strain used in the prediction is taken as 0.004 for ACI (2002) and fib (2001) codes, as specified in ACI 440.2R 08 (2002).

The resistance factors $\left(\phi_{c}, \phi_{f r p}\right)$ in ISIS (2001) are all set to equal to unity for calculating the nominal loading capacities. 
Table 8. Comparisons between compressive bearing capacity test results and design strengths using measured effective ultimate strain

\begin{tabular}{lcccc}
\hline Specimen & $N_{\text {exp }} / N_{\mathrm{GB}}$ & $N_{\text {exp }} / N_{\text {fib }}$ & $N_{\text {exp }} / N_{\text {ACI }}$ & $N_{\text {exp }} / N_{\text {ISIS }}$ \\
\hline CO-C-F1-IL & 1.00 & 0.91 & 1.06 & 1.15 \\
CO-C-F1-IL-R & 1.08 & 0.99 & 1.12 & 0.97 \\
\hline
\end{tabular}

